\title{
Comparing Risk Perceptions and Risk Management in Organic and Conventional Dairy Farming: Empirical Results From Norway
}

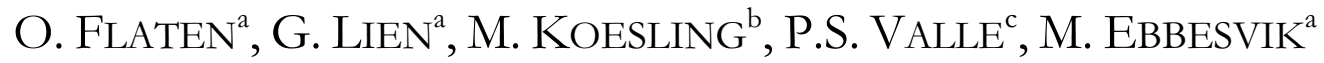 \\ aNorwegian Agricultural Economics Research Institute, Oslo, Norway \\ ${ }^{b}$ The Norwegian Centre for Ecological Agriculture, Tingvoll, Norway \\ Institute of Livestock. Medicine, The Norwegian School of Veterinary Science, Oslo, Norway
}

\begin{abstract}
This study was conducted to explore organic and conventional dairy farmers' perceptions of risk and risk management, and to examine relationships between farm and farmer characteristics, risk perceptions, and strategies. The data originate from a survey of conventional $(n=363)$ and organic $(n=162)$ dairy farmers in Norway. Organic farmers had the least risk averse perceptions. Institutional and production risks were perceived as primary sources of risk, with farm support payments at the top. Compared to their conventional colleagues, organic farmers gave more weight to institutional factors related to their production systems. Conventional farmers were more concerned about costs of purchased inputs and animal welfare policy. Organic and conventional farmers' management responses were more similar than their risk perceptions. Financial measures such as liquidity and costs of production, disease prevention, and insurance were perceived as important ways to handle risk. Even though perceptions were highly farmer-specific, a number of socio-economic variables were found to be related to risk and risk management. The primary role of institutional risks implies that policy makers should be cautious about changing policy capriciously and they should consider the scope for strategic policy initiatives that give farmers some greater confidence about the longer term. Further, researchers should pay more attention to institutional risks.
\end{abstract}

\section{Introduction}

Farmers' perceptions of and responses to risk are important in understanding their risk behaviour. In the literature much normative analysis (with mathematical programming etc.) has been done to show how farmers should behave under uncertainty (e.g. Hardaker et al., 2004). Surprisingly, however, less work has been done to examine how farmers perceive risk and manage it in practice. Organic farmers are exposed to additional and different sources of risk compared to conventional farmers. Restrictions on pesticide use, fertilisers, synthetic medicines, purchase of feeds etc. influence production risk. Smaller organic markets may mean greater price fluctuations. On the other hand, specific direct payments in organic farming result in greater income stability (Offer- 
mann and Nieberg, 2000, pp. 93). At the same time, and for both production types, uncertainty about future government payments may be of concern to farmers.

Surveys have been conducted asking about the types of risk perceived as most important by conventional farmers and about the management strategies the farmers use. Harwood et al. (1999) have summarised US studies. US farmers, included dairy farmers, were most concerned about commodity price risk, production risk, and changes in government laws and regulations. Arizona dairy producers perceived the costs of operating inputs to be the greatest source of risk (Wilson et al., 1993). A 1996 USDA survey (reported in Harwood et al., 1999) found that keeping cash on hand was the chief risk management strategy for every farm size, for every commodity speciality, and in every region studied. Use of derivative and insurance markets was also considered important. In a recent study (Hall et al., 2003), beef producers in Texas and Nebraska perceived severe droughts and cattle prices as the most important risk factors. Maintaining animal health was viewed as the most effective strategy.

Dairy farmers in New Zealand ranked price risk and rainfall variability highest, met by routine spraying, drenching and maintaining feed reserves (Martin, 1996). Meuwissen et al. (2001) found that Dutch livestock farmers considered price and production risks to be most important. Producing at lowest possible costs and insurance were the most important risk management strategies. A study among Finnish farmers found changes in agricultural policy as the most important risk factor, while maintaining adequate liquidity and solidity were the most important management responses (Sonkkila, 2002).

A few studies have found that geographic location, farm type, institutional structures and other factors affecting the operating environment of farmers influenced farmers' perceptions of risk and risk management (Boggess et al., 1985; Wilson et al., 1993; Patrick and Musser, 1997; Meuwissen et al. 2001). The studies also pointed to "the highly complex and individualistic nature of risk perceptions and selection of management tools" (Wilson et al., 1993).

As far as we know, no earlier studies have compared conventional and organic farmers' risk perceptions and risk management strategies. In Norway, no studies at all have explicitly investigated dairy farmers' risk perceptions and the ways they deal with the risks.

This relative lack of information about (especially organic) farmers' risky environment and their reactions to it means that there are few useful practical insights for policy makers, farm advisers and researchers. The objectives of this study are, through an exploratory and descriptive study, to provide empirical insight into: 1) Norwegian dairy farmers' risk perceptions and risk management responses; 2) differences in risk perceptions and management responses between conventional and organic dairy farmers; and 3) farm and farmer characteristics related to the perceptions and strategies. The data are analysed with modern multivariate techniques. 


\section{Conceptual framework}

Economists have traditionally used one theory of risky choice to serve both normative and descriptive purposes (Thaler, 2000). Expected utility theory is the most widely accepted normative model of rational choice (Meyer, 2000) that economists have used also as a descriptive model of decision making under risk (Thaler, 2000). Numerous studies have, however, criticised the expected utility hypothesis on descriptive grounds because it fails to describe observed behaviour (Kahneman and Tversky, 1979; Allais, 1984; Moschini and Hennessy, 2001, Rabin and Thaler, 2001). The best way to describe decisionmaking behaviour, according to Slovic et al. (1982), March and Shapira (1987) and Priem et al. (2002), is to understand the individual's frame of reference for evaluating choices with uncertain outcomes because the decision maker's perceptual world is that person's reality and forms the basis for her or his choices.

This paper will use a descriptive approach, where we aim to characterise how Norwegian dairy farmers perceive and manage risk. Because of organic farmers' exposure to additional and different sources of risk compared to conventional farmers, we expect these to influence their risk perceptions and management responses. For example, organic farmers purchase less of variable inputs, and we thus expect organic farmers to be less susceptible financially to input price shocks. The lack of earlier comparative studies, however, makes it hard to develop firm hypotheses. Instead, we will explore and identify differences between organic and conventional farmers in their assessed importance of various sources of risk and their management responses of these risks.

We do not expect either group of farmers to be a homogeneous population since we expect different farm and farmer characteristics to influence their risk perceptions and management responses. Van Raaij's (1981) model of the decision-making environment for the firm is useful to study the relationship between farm and personal characteristics, risk perceptions and management responses (e.g., Wilson et al., 1993). Figure 1 presents the groups of variables used in our research design. The other elements of Van Raaij's model are excluded.

First, $\mathrm{P} \rightarrow \mathrm{E} / \mathrm{P}$ describes how farm and personal variables $(\mathrm{P})$ impact on farmers' perceptions of risk factors $(\mathrm{E} / \mathrm{P})$. Second, the relationship $\mathrm{P} \rightarrow \mathrm{E} / \mathrm{P} \rightarrow \mathrm{B}$ reflects how the farm/personal variables and risk perceptions influence economic behaviour (B), i.e., their risk management strategies. Best use of intuition and prior insights from research in other countries were used in the selection of variables.

\section{Materials and methods}

\subsection{Data}

The data reported here were collected as a part of a larger questionnaire survey of risk and risk management in farming. Samples were selected from Nor- 
Figure 1. Elements of Van Raaij's (1981) model of a firm's decision-making environment

\begin{tabular}{|c|c|}
\hline $\mathrm{P}$ \\
\hline $\begin{array}{c}\text { Farm and farmer } \\
\text { characteristics }\end{array}$ & $\mathrm{E} / \mathrm{P}$ \\
$\begin{array}{c}\text { Risk } \\
\text { perceptions }\end{array}$ & $\mathrm{B}$ \\
\hline $\begin{array}{c}\text { Economic } \\
\text { behaviour }\end{array}$ \\
\hline
\end{tabular}

wegian crop and dairy farmers. This paper examines data from dairy farmers; an analysis of the data from crop farmers is reported in Koesling et al. (2004). Because of small herd sizes in Norway, dairy farms were defined as farms having more than five dairy cows.

The 10-page questionnaire consisted of questions related to: 1) farmers' perceptions of risk (including questions on risk attitude and sources of risk); 2) farmers' perceptions of various risk management strategies; 3) farmers' goals, future plans and motivations for their farming system (organic or conventional); 4) animal disease management strategies; and 5) characteristics of the farm and farmer. Most questions were of the closed type, many in the form of seven point Likert-type scales. The questionnaire was both pre-tested internally and in sessions with farmers, and refined over several stages based on the comments and suggestions received.

The Norwegian Agricultural Authority (SLF) has a register of farmers who receive support payments (i.e. all farmers), including each farmer's stocking and cropping details. Dairy cow health and production records are registered in the Norwegian Herd Recording System, in which $96.5 \%$ of the dairy farmers participate (Østerås, 2003). These two data sets (2002-data) were merged with the survey data.

\subsection{Sample}

The questionnaire was first sent out in January 2003 to 616 randomly selected conventional dairy farmers and all 245 registered organic dairy farmers. Conventional farmers were selected from the SLF-register of farmers who received support payments based on their 2001 application. A month later a reminder post card was sent to all non-respondents. In March, non-respondents were mailed with a follow-up letter and another copy of the questionnaire.

From the original 861 dairy farmers approached (in 2001), 383 (62.2\%) conventional and $161(65.7 \%)$ organic farmers responded. Six conventional respondents informed us that they had quit farming. Seven conventional and two organic farmers had quit dairying. Five dairy respondents had converted to organic farming methods and one from organic to conventional farming. Two originally non-dairy respondents had started organic dairy farming. Three conventional and three organic responses were discarded because of very incomplete returns. The questionnaires of 363 conventional and 162 organic farmers 
Table 1: Number of unanswered questions on sources of risk ${ }^{a}(n=31)$ across risk management strategies $(n=25)$ within categories of groups

\begin{tabular}{|c|c|c|c|c|c|c|c|}
\hline & & & & Sou & of risk & & \\
\hline & Groups & 0 & $1-5$ & 6-11 & $12-20$ & $>20$ & Total \\
\hline & 0 & 315 & 78 & 2 & 1 & 3 & 399 \\
\hline$\stackrel{\infty}{\Xi}$ & $1-5$ & 65 & 33 & 2 & 0 & 1 & 101 \\
\hline 承 & $6-13$ & 6 & 4 & 0 & 0 & 0 & 10 \\
\hline 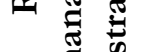 & $>13$ & 7 & 1 & 2 & 0 & 5 & 15 \\
\hline & Total & 393 & 116 & 6 & 1 & 9 & 525 \\
\hline
\end{tabular}

a A total of 33 variables were presented, but two crop farm specific sources of risk are excluded

(in 2002/2003) were then available for statistical analysis. Because of the sampling strategy used and the high response rate, the samples are assumed to be representative of the conventional and organic dairy farmer populations.

\subsection{Statistical analyses}

All computations were conducted using the SAS statistical program package (v 8.2). As a first step, farmers' perceptions of risk and risk management were studied using descriptive statistical analyses. Mean values obtained in organic and conventional farming for a variable were compared by $t$-tests, omitting an observation if it had a missing value. Standard parametric statistical procedures were assumed appropriate for ordinal variables in the form of Likert-type scales (e.g. Patrick and Musser, 1997; Meuwissen et al., 2001).

Common factor analysis, from an exploratory perspective, was employed to summarise the information in a reduced number of factors. The latent root criterion (eigenvalue $>1$ ) was first used as a guideline in determining how many factors to extract. In order to have the most representative and parsimonious set of factors possible, factor solutions with different numbers of factors were also examined before structures were defined (Hair et al., 1998). Orthogonal (varimax) rotation was used, to ensure inter alia that the factors were as independent as possible for subsequent use in regressions. Standardised factor scores for each farmer and factor were saved for subsequent multivariate analyses.

Some $40 \%$ of the respondents did not answer one or more relevant questions about sources of risk or management responses (Table 1). In cases with missing data, most of the respondents failed to answer only a few items. If remedies for missing data are not applied, any observations with missing values on any of the items are omitted. Using only complete observations can produce bias in the results unless the missing observations are missing completely at random. There is also a loss of precision as the sample size is reduced (Hair et al., 1998). Our approach for dealing with missing data in these factor analyses was first to delete cases having answered less than 20 of the risk source vari- 
ables or 12 of the risk management strategies variables. Next, missing data points were replaced with the mean value of that variable based on all valid responses in the group (conventional or organic).

Organic and conventional farmers may have different risk perceptions but some preliminary analyses revealed very similar factor structures among risk sources and management responses. Therefore joint factor analyses for the two groups of farmers were carried out.

The factor scores from the risk attitude questions were submitted to a nonhierarchical cluster analysis to search for groupings of farmers with similar risk attitudes. The sequential threshold method combined with the least square optimisation criterion was used to select cluster seeds (Hair et al., 1998). Creating the risk attitude variable by use of cluster analysis, rather than identifying the risk groups by using e.g. median split, reduces the chance of arbitrariness when identifying groups.

Multiple (ordinary least square and logistic) regressions were used to study associations between farm and farmer characteristics, risk perceptions and risk management, as outlined in figure 1. An observation was excluded from the analysis, if any variable needed for a regression was missing, for example a categorical farm or farmer characteristic. Simple correlation coefficients between all pairs of independent variables were low. Variance inflation factors were close to 1 and condition indices were low, indicating no multicollinearity problems (Belsley et al., 1980). No heteroskedasticity was detected using the White test (White, 1980). The stepwise regression method was tested. Compared to the complete models, signs of the coefficients were identical, magnitudes of the coefficients were quite similar, and the levels of statistical significance of the independent variables were almost stable. The complete regression models were selected for reporting herein.

\section{Results and discussion}

\subsection{General characteristics of respondents}

The main characteristics of the dairy farm groups are compared in Table 2. The average farm size of conventional respondents was slightly larger than the average in Norway. Respondents were somewhat younger than the average dairy farmer.

Organic respondents farmed more land on average than conventional respondents. Average numbers of dairy cows were quite similar between the two groups, but organic cows were fed less concentrate and produced less milk. Labour input and farmers' age were quite similar on conventional and organic farms. Organic farmers had most years of schooling and more of them had agricultural education. Most respondents were organised as family 
Table 2: Comparison of average characteristics of dairy farms in survey with averages of dairy farms in Norway ${ }^{a}$

\begin{tabular}{|c|c|c|c|c|}
\hline \multirow[t]{2}{*}{ Characteristics } & \multicolumn{2}{|c|}{ Conventional } & \multicolumn{2}{|c|}{ Organic } \\
\hline & $\begin{array}{l}\text { Survey } \\
(\mathrm{n}=363)\end{array}$ & $\begin{array}{l}\text { Norway } \\
(18,300)^{\mathrm{b}}\end{array}$ & $\begin{array}{c}\text { Survey } \\
(\mathrm{n}=162)\end{array}$ & $\begin{array}{c}\text { Norway } \\
(325)^{b}\end{array}$ \\
\hline Number of dairy cows ${ }^{b}$ & 16.9 & 15.8 & 16.8 & 16.8 \\
\hline Milk yield per $\operatorname{cow}^{\mathrm{c}}(\mathrm{kg})$ & 6193 & 6150 & 5119 & 5070 \\
\hline Concentrates $\left(\mathrm{FUm}^{\mathrm{d}} / \mathrm{cow}\right)$ & 1649 & 1706 & 887 & 866 \\
\hline Farmland $(\mathrm{ha})^{\mathrm{b}}$ & 25.8 & 23.3 & 30.3 & 30.2 \\
\hline Labour units (man-years) & 2.1 & - & 2.1 & - \\
\hline Age of farmerb & 47.5 & 51.6 & 47.2 & 52.1 \\
\hline Highest level of educatione (\%) & $17 / 70 / 10 / 3$ & - & $6 / 54 / 22 / 18$ & - \\
\hline Agricultural education $(\%)$ & 59.7 & - & 76.1 & - \\
\hline Farm income $e^{f}(\%)$ & 54.8 & - & 46.8 & - \\
\hline Household incomeg $(\%)$ & 42.2 & - & 50.3 & - \\
\hline
\end{tabular}

a Information was also gathered on net worth and debt. Many refusals to answer precluded their use in the statistical analyses.

b Data (2002) from the Norwegian Agricultural Authority.

${ }^{c}$ Data (2002) from the Norwegian Herd Recording System.

d One feed unit milk (FUm) is defined as $6900 \mathrm{~kJ}$ of net energy lactation (Ekern, 1991).

e Primary school / high school / BSc / MSc.

f Percentage of respondents (spouse included) with farm income $\geq$ NOK (Norwegian kroner) 200000 . $€ 1 \approx$ NOK 8.40 .

$g$ Percentage of respondents (spouse included) with household income $\geq$ NOK 350000 . Household income covers farm income, other forms of self-employment, wages, pensions, property income and capital income.

farms: $93 \%$ of conventional and $88 \%$ of organic farms. Partnerships occurred on $6 \%$ of the farms.

\subsection{Farmer's willingness to take risk}

Farmers were asked to assess their willingness to take risk, compared to others, on Likert-type scales ranging from 1 (do not agree) to 7 (fully agree). The statements were "I am willing to take more risk than other with respect to: 1) production; 2) marketing; and 3) finance and investment", respectively. Patrick and Musser (1997) and Meuwissen et al. (2001) used similar statements. ${ }^{119} \mathrm{We}$ assumed that most farmers are risk averse, but they vary in their willingness to take risk (Hardaker et al., 2004, pp. 92). Since statements measured attitude toward risks compared to others, the term comparative risk aversion (CRA) was used. Figure 2 compares the percentage distribution of organic and conventional respondents' answers in relationship to the statements.

119 The measures used to elicit farmers' risk preferences in all these studies, including ours, is a simple approximation. More advanced methods to elicit farmers' risk attitude is discussed in, e.g., Moschini and Hennessy (2001) and Hardaker et al. (2004). 
Figure 2. Percentage distribution of organic and conventional respondents' comparative risk aversion

\section{Conventional}

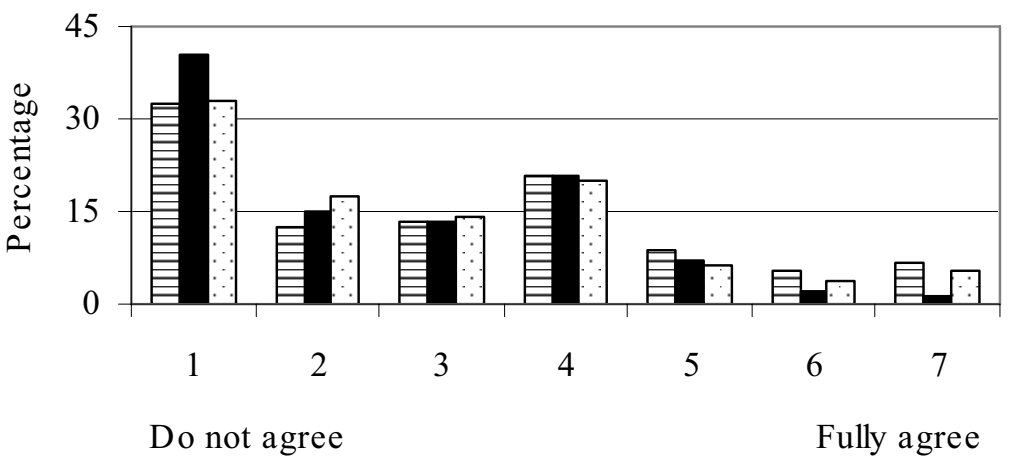

Organic

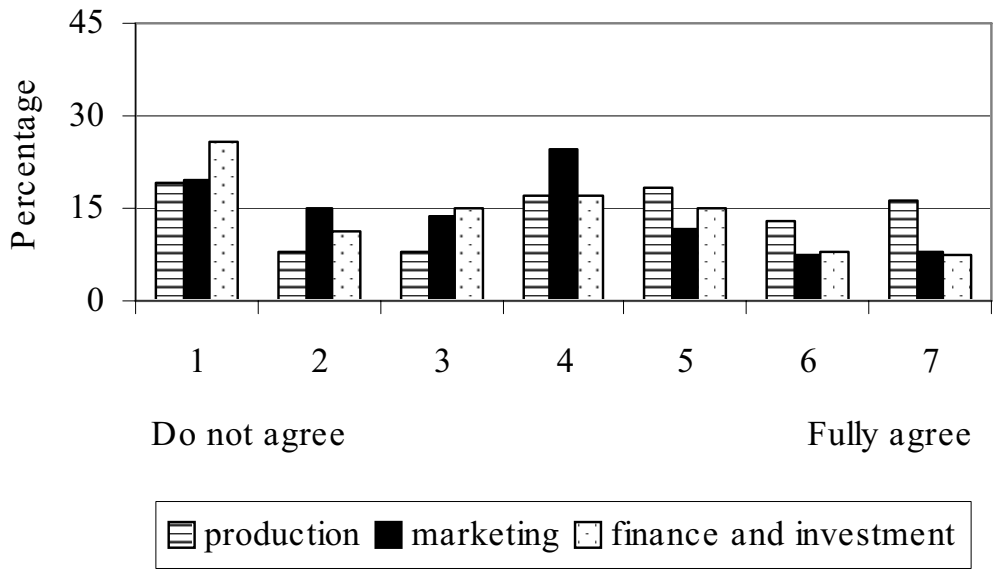

Conventional dairy farmers generally perceived the extent to which they take risks to be less than that of others. By contrast, figure 2 shows that the responses of the organic dairy farmers had a more symmetric distribution over the scale of comparative risk aversion, especially with respect to production risks. Organic farmers' assessments were significantly less risk averse than their conventional colleagues (both production and marketing $P<0.001$, finance and investment $P<0.01)$. Organic farmers have been few in numbers and the amount of experience with this form of production is somewhat restricted. Some willingness to take risk should therefore be expected among those adopting organic farming practices. Using historical data, Gardebroek (2002) also found organic farmers to be less risk averse than their non-organic colleagues. 
Table 3: Mean score for conventional and organic farmers, and joint varimax rotated factor loadings for sources of risk (by declining importance for conventional farmers)

\begin{tabular}{|c|c|c|c|c|c|c|c|c|c|}
\hline \multirow[t]{2}{*}{ Sources of risk } & \multirow{2}{*}{$\begin{array}{l}\text { Conv. } \\
\text { mean }^{\mathrm{b}}\end{array}$} & \multirow{2}{*}{$\frac{\text { Org. }}{\text { mean }}$} & \multirow{2}{*}{$\begin{array}{c}\text { Org. } \\
\text { rank }\end{array}$} & \multicolumn{6}{|c|}{ Most important factors ${ }^{\mathrm{a}}$} \\
\hline & & & & 1 & 2 & 3 & 4 & 5 & 6 \\
\hline Changes in gov. support payments & ${ }^{* *} 5.90$ & 5.56 & $(1)$ & 0.02 & 0.43 & 0.00 & 0.21 & 0.20 & 0.19 \\
\hline Changes in tax policy & $* * * 5.86$ & 4.99 & (6) & 0.15 & 0.50 & -0.13 & 0.20 & 0.22 & 0.24 \\
\hline Milk price variability & ***5.81 & 5.28 & (2) & 0.26 & 0.45 & -0.08 & 0.19 & 0.47 & 0.01 \\
\hline Milk quota policy & $* * * 5.56$ & 4.83 & (9) & 0.22 & 0.50 & 0.02 & 0.06 & 0.31 & 0.02 \\
\hline Meat price variability & $* * * 5.55$ & 4.72 & (10) & 0.26 & 0.43 & -0.08 & 0.20 & 0.37 & 0.06 \\
\hline Animal welfare policy & $* * * 5.40$ & 4.17 & (17) & 0.22 & 0.69 & -0.03 & -0.10 & -0.12 & 0.07 \\
\hline Costs of operating inputs & $* * * 5.23$ & 3.98 & (21) & 0.27 & 0.40 & -0.17 & 0.36 & 0.28 & 0.09 \\
\hline Injury, illness, death of operator(s) & 5.18 & 5.05 & $(5)$ & 0.15 & 0.16 & 0.09 & 0.07 & 0.17 & 0.75 \\
\hline Changes in consumer preferences & 5.17 & 5.10 & (4) & 0.13 & 0.05 & 0.04 & 0.04 & 0.58 & 0.15 \\
\hline Non-domestic epidemic animal dis. & **5.10 & 4.53 & (13) & 0.53 & 0.19 & 0.06 & 0.07 & 0.01 & 0.27 \\
\hline Domestic epidemic animal diseases & ***4.96 & 4.16 & (18) & 0.74 & 0.19 & -0.02 & 0.08 & -0.01 & 0.24 \\
\hline Forage yields uncertainty & 4.86 & 4.84 & (8) & 0.53 & 0.02 & 0.09 & 0.17 & 0.32 & 0.06 \\
\hline Other gov. laws and regulations & ${ }^{*} 4.78$ & 4.40 & (14) & 0.13 & 0.52 & 0.19 & 0.20 & -0.02 & 0.17 \\
\hline Cost of capital equipment & $* * * 4.74$ & 3.87 & (25) & 0.30 & 0.37 & -0.09 & 0.33 & 0.21 & 0.10 \\
\hline Fire damages & ${ }^{* * *} 4.59$ & 3.86 & (26) & 0.44 & 0.19 & -0.01 & 0.19 & 0.03 & 0.40 \\
\hline Cost of credit (interest rate) & ${ }^{* *} 4.51$ & 3.97 & (22) & 0.22 & 0.08 & 0.02 & 0.73 & 0.08 & 0.07 \\
\hline Crop prices variability & 4.47 & 4.25 & (16) & d. & d. & d. & d. & d. & d. \\
\hline Technical failure & $* * * 4.46$ & 3.90 & (24) & 0.42 & 0.23 & 0.02 & 0.28 & 0.13 & 0.20 \\
\hline Meat production variability & ***4.43 & 3.71 & (27) & 0.57 & 0.25 & 0.05 & 0.20 & 0.25 & 0.09 \\
\hline Family members' health situation & 4.40 & 4.11 & (19) & 0.24 & 0.16 & 0.07 & 0.10 & 0.13 & 0.56 \\
\hline Marketing/sale & $* 4.35$ & 4.65 & (11) & 0.09 & 0.01 & 0.18 & 0.01 & 0.54 & 0.08 \\
\hline Changes in technology & $* * * 4.35$ & 3.68 & (28) & d. & d. & d. & d. & d. & d. \\
\hline Crop yields variability & 4.33 & 4.37 & (15) & d. & d. & d. & d. & d. & d. \\
\hline Legislation in production hygiene & 4.28 & 3.93 & (23) & 0.24 & 0.62 & 0.18 & -0.06 & -0.08 & 0.09 \\
\hline Production diseases & $* 4.23$ & 3.61 & (29) & 0.67 & 0.20 & 0.03 & 0.11 & 0.14 & 0.06 \\
\hline Milk yield variability & *4.17 & 3.53 & (30) & 0.52 & 0.25 & 0.04 & 0.19 & 0.21 & -0.03 \\
\hline Hired labour & 3.86 & 4.06 & (20) & d. & d. & d. & d. & d. & d. \\
\hline Credit availability & 3.57 & 3.28 & (33) & 0.22 & 0.09 & 0.16 & 0.65 & 0.02 & 0.11 \\
\hline Uncertainty about family relations & 3.31 & 3.30 & (32) & d. & d. & d. & d. & d. & d. \\
\hline Leasing farm land & 3.31 & 3.40 & (31) & d. & d. & d. & d. & d. & d. \\
\hline Add. organic farming payments & $* * * 2.67$ & 5.24 & (3) & 0.07 & 0.05 & 0.84 & 0.02 & 0.05 & 0.05 \\
\hline Organic farming laws/regulations & $* * * 2.27$ & 4.63 & (12) & 0.02 & 0.08 & 0.88 & 0.02 & 0.06 & 0.08 \\
\hline Price premiums organic products & $* * * 2.24$ & 4.91 & $(7)$ & 0.02 & -0.07 & 0.88 & 0.08 & 0.09 & 0.00 \\
\hline Percent of total variance explained & - & - & - & 11.9 & 10.7 & 9.2 & 6.2 & 6.0 & 5.3 \\
\hline Cum. $\%$ of the variance explained & - & - & - & 11.9 & 22.6 & 31.8 & 38.0 & 44.0 & 49.2 \\
\hline
\end{tabular}

a Factors 1 to 6 are production, institutional, organic farming, credit, consumer demand, and human resources, respectively. Factor loadings $>|0.30|$ are in bold. "d." means that the variable is deleted from the factor analysis because of low factor loading and low communality or farm-type conditionality.

b Mean score $(1=$ no impact, $7=$ very high impact $)$ for conventional farmers $(\mathrm{n}=363)$ and organic farmers $(\mathrm{n}=$ 162). Mean numbers marked with asterisks show that the mean scores of conventional and organic farmers are significant different at $* \mathrm{P}<0.05$, ** $\mathrm{P}<0.01$ and ${ }^{* * *} \mathrm{P}<0.001$, based on independent samples t-test.

The three risk attitude questions all had significant positive correlations $(P<0.001)$ ranging from 0.57 to 0.62 . Kaiser's overall measure of sampling adequacy (MSA) was 0.717, suggesting that the matrix was suitable for factor analysis (Hair et al., 1998). Factor analysis of the variables resulted in a single factor with all three variables loading at 0.76 or higher and accounting for $73.7 \%$ of the total variance. The three risk attitude measures were summarised in a single variable (factor score). 
The single factor scores from the factor analysis were used as input data in the cluster analysis; by this means it was possible to identify three distinct risk aversion clusters among the respondents. The cluster groups consisted of 210 farmers with "high risk aversion", 201 with "medium risk aversion" and 110 with "low risk aversion". Four respondents were excluded because of missing data. The three ordered categories of risk aversion were used in subsequent regressions.

\subsection{Perceptions of sources of risk}

In total, 33 sources of risk were presented to the respondents. Farmers were asked to score each source of risk on a Likert-scale from 1 (no impact) to 7 (very high impact) to express how significant they considered each source of risk to be in terms of its potential impact on the economic performance of their farm. The second and third columns of Table 3 compare average scores for conventional and organic farmers. ${ }^{120}$ The fourth column shows organic farmers' ranking.

Uncertainty about the continuation of general government support payments stands out as the top-rated source of risk for both groups. Target prices and support schemes are decided in Norway through annual negotiations between the two farmers' unions and the Government. High average rankings related to milk and meat prices are thus linked to farm policy. Other highly ranked risks in general were institutional risks such as tax policy and milk quota policy.

Sources of risk that scored low include farmland leasing, family relations, credit availability, milk yield, production diseases, and hired labour.

Conventional farmers assigned more importance than organic farmers to many of the listed sources of risk. The less risk averse perceptions of organic farmers may have influenced the mean scores. The most pronounced differences were found in costs of operating inputs, animal welfare policy, and cost of capital equipment. The finding that organic farmers ranked input costs risk lower than conventional farmers is probably a result of production systems in organic farming with low levels of purchased inputs. At the time the survey was held a white paper on animal welfare was prepared (LD, 2002), maybe influencing the high score conventional farmers gave to animal welfare policy risks. Less pronounced anxiety among organic farmers for this source of risk is presumably because of already strict organic animal welfare standards. Organic farmers gave high scores to the specific, institutional "organic sources of risk" (the last three sources in Table 3). Beyond these, marketing/sales was the only source of risk where organic farmers' mean score was significantly higher than

120 The standard deviations are not presented in Tables 3 and 4 because of the large size of the tables. The results are available from the authors. 
that for conventional farmers, maybe reflecting the higher instability in organic product markets.

Comparisons of risks (and management strategies) with previous studies are difficult because different questions were asked. Further, different farming, cultural and risk environments complicate cross-national comparisons. However, the most outstanding finding, compared to previous US, NZ, and Dutch studies, is the very high scores of many institutional risks. Agricultural policy changes, however, scored high in Finland (Sonkkila, 2002).

Since farming is typically a risky business, governments around the world have intervened to varying degrees to try to help farmers cope more effectively with risk. In this context it is a paradox that farmers perceived institutional risks as the most important. The domination of institutional risks may be related to somewhat unpredictable changes in Norwegian farm policies and regulations, together with external pressures for deregulation and associated fears of farm support cuts. The finding should also be linked to Just's (2003) proposal that longer term swings (e.g. lasting changes in agricultural policy) represent a much greater risk to farmers than year-to-year variability in payoffs because the downside consequences may be sufficiently prolonged to cause farm failure.

Joint factor analysis was applied to the data to reduce the number of risk source variables. The overall MSA was 0.850 , suggesting the matrix was suitable for factor analysis. The number of variables was reduced from 33 to 6. Some $49.2 \%$ of the total variance was accounted for. The latent root criterion suggested seven factors. The six-factor solution gave the most interpretable factors and was judged to be most useful. Variables conditional on farm type (crop yields and prices) were not included. Variables that did not load significantly on any factor (i.e. loadings $<|0.30|$ ) or whose communalities were low $(<0.25)$ were also evaluated for possible deletion. Table 3 displays the six factors and their respective loading items after elimination of some variables.

The factors 1 to 6 are labelled "production", "institutional", "organic farming", "credit", "consumer demand", and "human resources" respectively. Factor 1 , production, loads significantly from a variety of production variables and has the highest loadings of animal disease variables. A wide collection of public payment and government legislation variables indicates institutional risks in factor 2. Significant loadings of output and input prices could reflect the government's role in the pricing. Factor 3 is called organic farming because of the extremely high loadings of the three specific, institutional "organic" variables. Factor 4, credit, has large loadings of the interest rate and credit availability. Significant loadings of purchased inputs are likely to reflect the use of credit to these purposes in a farm business. Factor 5, consumer demand, involves high loadings of consumer preferences and marketing. Not surprisingly, some output price cross loadings are also significant. Heavy loadings of health and family variables and a cross loading of 0.40 of fire damage suggests human resources for factor 6 . 
Table 4 Mean score for conventional and organic farmers, and joint varimax rotated factor loadings for risk management strategies. Ranked by declining importance for conventional farmers

\begin{tabular}{|c|c|c|c|c|c|c|c|c|c|c|}
\hline \multirow{2}{*}{$\begin{array}{l}\text { Risk management } \\
\text { strategies }\end{array}$} & \multirow{2}{*}{$\begin{array}{l}\text { Conv. } \\
\text { mean }^{b}\end{array}$} & \multirow{2}{*}{$\begin{array}{l}\text { Org. } \\
\text { mean }\end{array}$} & \multirow{2}{*}{$\begin{array}{l}\text { Org. } \\
\text { rank }\end{array}$} & \multicolumn{7}{|c|}{ Most important factors ${ }^{a}$} \\
\hline & & & & 1 & 2 & 3 & 4 & 5 & 6 & 7 \\
\hline Liquidity - keep cash in hand & ${ }^{* *} 6.50$ & 6.19 & $(1)$ & 0.08 & 0.20 & 0.07 & 0.20 & -0.06 & 0.50 & $\overline{0.02}$ \\
\hline Prev./red. livestock diseases & $* 6.35$ & 6.13 & (2) & 0.06 & 0.64 & 0.03 & 0.27 & -0.09 & 0.22 & 0.10 \\
\hline Buying farminsurance & ${ }^{*} 6.13$ & 5.80 & (3) & 0.19 & 0.22 & 0.05 & 0.63 & -0.04 & 0.11 & -0.04 \\
\hline Producing allower cost & ${ }^{* *} 5.94$ & 5.61 & (5) & 0.09 & 0.29 & 0.03 & 0.09 & -0.02 & 0.33 & 0.18 \\
\hline Buying personal insurance & **5.92 & 5.50 & (6) & 0.16 & 0.12 & 0.07 & 0.83 & 0.12 & 0.08 & 0.16 \\
\hline Risk reducing technologies & 5.73 & 5.67 & (4) & 0.23 & 0.46 & 0.12 & 0.12 & 0.06 & 0.10 & 0.18 \\
\hline Solvency - debt management & $* * * 5.65$ & 5.16 & (9) & -0.05 & 0.02 & 0.06 & -0.02 & 0.13 & 0.78 & -0.05 \\
\hline Prevent/reduce dis. and pests & 5.52 & 5.39 & (7) & 0.07 & 0.71 & 0.24 & 0.05 & 0.12 & 0.04 & 0.05 \\
\hline Use of agron. Nutr. cons. Serv. & *5.44 & 5.06 & (10) & 0.66 & 0.13 & -0.03 & 0.12 & -0.01 & 0.00 & 0.10 \\
\hline Small gradual changes & 5.38 & 5.18 & $(8)$ & d. & d. & d. & d. & d. & d. & d. \\
\hline Cooperative marketing & ***5.35 & 4.78 & (12) & d. & d. & d. & d. & d. & d. & d. \\
\hline Use of veter cons./serv. & ***5.09 & 4.31 & (16) & 0.65 & 0.11 & 0.08 & 0.07 & 0.07 & 0.10 & 0.03 \\
\hline Asset flexibility & 4.88 & 4.94 & (11) & 0.01 & 0.06 & 0.47 & 0.03 & 0.23 & 0.13 & 0.19 \\
\hline Shared eqmt. part.ship & 4.87 & 4.64 & (14) & 0.13 & 0.14 & -0.08 & 0.03 & 0.18 & -0.01 & 0.66 \\
\hline Keeping fixed costs low & 4.61 & 4.69 & (13) & 0.09 & 0.07 & 0.09 & 0.05 & 0.02 & 0.03 & 0.39 \\
\hline Use of econ. consult. services & 4.44 & 4.14 & (19) & 0.66 & 0.00 & 0.11 & 0.14 & 0.20 & -0.03 & 0.15 \\
\hline Enterprise diversification & 4.28 & 4.41 & (15) & 0.04 & 0.11 & 0.21 & -0.09 & 0.33 & 0.00 & 0.18 \\
\hline Storage & 4.16 & 4.08 & (20) & 0.05 & 0.12 & 0.58 & 0.07 & -0.11 & 0.08 & -0.15 \\
\hline Prod. contracts & 4.07 & 4.03 & (21) & 0.17 & 0.15 & 0.42 & 0.07 & 0.07 & 0.03 & -0.04 \\
\hline Off-farm work & 4.02 & 4.01 & (22) & 0.09 & 0.03 & -0.02 & 0.05 & 0.41 & 0.10 & 0.10 \\
\hline Information & *3.79 & 4.22 & (18) & 0.19 & 0.14 & 0.24 & -0.01 & 0.34 & -0.06 & 0.17 \\
\hline Prod. and market flexibility & $* * * 3.40$ & 4.24 & (17) & -0.12 & -0.02 & 0.63 & -0.05 & 0.14 & -0.05 & 0.39 \\
\hline Surplus mach.ry capacity & $* 3.39$ & 3.05 & (23) & d. & d. & d. & d. & d. & d. & d. \\
\hline Off-farm investments & 2.68 & 2.60 & (24) & 0.01 & -0.10 & 0.05 & 0.04 & 0.70 & -0.04 & -0.05 \\
\hline Organise the farm as a corp. & 2.39 & 2.20 & (25) & d. & d. & d. & d. & d. & d. & d. \\
\hline$\%$ of total var. explained & - & - & - & 7.3 & 7.0 & 6.5 & 6.2 & 5.3 & 5.2 & 4.8 \\
\hline Cum. $\%$ of the var. explained & - & - & - & 7.3 & 14.3 & 20.7 & 26.9 & 32.2 & 37.4 & 42.2 \\
\hline
\end{tabular}

\subsection{Perceptions of risk management strategies}

Some 25 risk management strategies were presented for the farmers' consideration. Farmers indicated their perceived importance of each strategy on a Likertscale from 1 (not relevant) to 7 (very relevant). Results are reported in Table 4.

Strategies generally perceived as very relevant were good liquidity, prevent and reduce livestock diseases, buy farm business insurance and personal insurance and produce at lowest possible cost. In recent studies of livestock farmers in other countries the same strategies were also perceived as most important (Meuwissen et al., 2001; Hall et al., 2003), even though national risk environments are quite different. 
Farmers generally did not see corporate farm organisation, off-farm investments, surplus machinery capacity, collecting information, off-farm work and use of price contracts as important strategies. The low ranking of collecting information could be a negative response to the need to collect still more information (inter alia related to quality assurance schemes) than to the importance of collecting information per se. Time-intensive dairy farming does not lend itself to off-farm work strategies, but $43 \%$ of the respondents perceived off-farm work as an important strategy (a score of 5 or higher). The low mean score assigned to price contracts may be because of the extensive use of cooperative marketing among Norwegian farmers and the Norwegian agricultural policy system, but livestock farmers in more deregulated countries have also ranked derivative instruments low (Martin, 1996; Meuwissen et al., 2001; Hall et al., 2003).

Organic and conventional farmers perceptions of the importance of different management responses were much more similar than their perceptions about the sources of risk. Conventional farmers attached particularly greater importance than organic farmers to veterinary services, cooperative marketing and solvency (debt management). The differences may be attributable to differences between the two production systems and the high importance of "noneconomic" goals among organic farmers. Organic farmers assigned significantly higher scores only to product and market flexibility and collecting information, but neither of these belonged to the risk strategies assigned high importance.

The overall MSA for the risk management variables was 0.736 , suggesting the matrix was suitable for factor analysis. The joint factor analysis identified seven factors with eigenvalues greater than one accounting for $42.2 \%$ of the variance. This solution gave interpretable and feasible factors and was used in the further analysis. Candidates for deletion were assessed in the same way as for the sources of risk. Table 4 displays the seven factors and their respective loading items after deletion of some variables.

The factors 1 to 7 are interpreted as "consultancy", "disease prevention", "flexibility", "insurance", "diversification", "financial" and "fixed cost sharing" respectively. Factor 1, consultancy, has high loadings of the consultancy services (veterinarian, agronomy/nutrition, and economics). Factor 2 is named disease prevention because of large loadings of prevention/reduction of crop/forage and livestock diseases and pests. A significant loading of risk reducing technologies accompanies the disease prevention strategies. Factor 3, flexibility, includes on-farm strategies to enhance flexibility (storage included) and price contracts. Factor 4 has heavy loadings of insurance contracts, and is accordingly labelled insurance. Off-farm (investments and work) and on-farm strategies to spread risk are included in factor 5, diversification. A significant loading of collecting information is also included. Factor 6 includes financial aspects of the farm business (solvency, liquidity, and production costs). Controlling fixed costs through shared ownership of equipment and partnership loads high on factor 7 , fixed cost sharing. Moreover, another fixed cost strat- 
Table: 5 Results of multiple regressions for comparative risk aversion (CRA) and sources of risk against socio-economic variables ${ }^{\mathrm{a}}, \mathrm{n}=457$

\begin{tabular}{|c|c|c|c|c|c|c|c|}
\hline \multirow{2}{*}{$\begin{array}{l}\text { Independent } \\
\text { variables }\end{array}$} & \multirow[t]{2}{*}{$\mathrm{CRA}^{\mathrm{b}}$} & \multicolumn{6}{|c|}{ Sources of risk } \\
\hline & & Production & Institutional & $\begin{array}{l}\text { Organic } \\
\text { farming }\end{array}$ & Credit & $\begin{array}{c}\text { Consumer } \\
\text { demand }\end{array}$ & $\begin{array}{l}\text { Human } \\
\text { resources }\end{array}$ \\
\hline Farming system ${ }^{c}$ & $* * * 0.96$ & $* * *-0.35$ & $* * *-0.52$ & $* * * 1.40$ & $*-0.23$ & 0.02 & -0.01 \\
\hline CRA: $m a-m^{d}$ & n.i. & 0.01 & 0.09 & -0.05 & -0.09 & $* * 0.28$ & (*) 0.16 \\
\hline CRA: la-m ${ }^{\mathrm{d}}$ & n.i. & 0.05 & 0.00 & 0.00 & 0.10 & $* * 0.31$ & -0.04 \\
\hline Ownershipe & -0.06 & 0.12 & -0.24 & -0.16 & 0.03 & 0.00 & 0.19 \\
\hline Nr. of cows & $* 0.03$ & -0.01 & -0.01 & 0.00 & (*) 0.01 & 0.01 & 0.00 \\
\hline Farm exp.ce (yrs) & -0.00 & 0.00 & 0.00 & 0.00 & 0.00 & 0.00 & 0.00 \\
\hline Education ${ }^{\mathrm{f}}$ & -0.07 & -0.01 & 0.10 & 0.02 & 0.07 & -0.03 & 0.02 \\
\hline Ag. educationg & 0.13 & -0.08 & -0.09 & (*) -0.14 & 0.07 & 0.13 & 0.00 \\
\hline Off-farm work ${ }^{\mathrm{h}}$ & (*) 0.39 & 0.00 & 0.02 & -0.13 & 0.03 & (*) 0.14 & 0.06 \\
\hline Off-farm invest. ${ }^{i}$ & -0.02 & 0.01 & 0.04 & 0.08 & $* * *-0.29$ & -0.12 & 0.05 \\
\hline SGM dairy $(\%)^{i}$ & 0.34 & -0.10 & 0.40 & -0.19 & -0.02 & -0.31 & -0.34 \\
\hline Farm income $e^{k}$ & $*_{-} 0.49$ & -0.04 & 0.04 & 0.01 & 0.05 & -0.03 & -0.04 \\
\hline H.hold income & 0.34 & -0.14 & -0.13 & -0.12 & -0.11 & -0.05 & -0.02 \\
\hline Geography ${ }^{\mathrm{m}}$ & 0.30 & $* 0.23$ & 0.10 & -0.02 & -0.11 & 0.03 & -0.10 \\
\hline $\mathrm{R}^{2}{ }_{\mathrm{adj}}^{\mathrm{n}}$ & $* * * 0.121$ & $* * * 0.029$ & $* * * 0.081$ & $* * * 0.433$ & $* * 0.037$ & $* 0.023$ & 0.000 \\
\hline
\end{tabular}

a Variables and models significant at $\left.{ }^{*}\right) \mathrm{P}<0.10,{ }^{*} \mathrm{P}<0.05,{ }^{*} \mathrm{P}<0.01$ and ${ }^{* * *} \mathrm{P}<0.001$. "n.i." stands for "not included".

${ }^{\mathrm{b}}$ Measured as an ordered response variable where 1 denotes the most risk averse attitude, 2 the medium and 3 the least.

${ }^{c}$ Measured as a dummy variable where 1 denotes organic farming and 0 denotes conventional farming.

d Measured as two dummy variables "ma-m" and "la-m" where 0 denotes the medium risk averse attitude (m), and

1 denotes the most risk averse attitude (ma) and the least risk averse attitude (la), respectively.

e Measured as a dummy variable where 1 denotes partnerships and 0 denotes otherwise.

${ }^{\mathrm{f}}$ Measured as a dummy variable where 1 denotes formal schooling beyond high school and 0 denotes high school education or less.

$\mathrm{g}$ Measured as a dummy variable where 1 denotes agricultural education and 0 denotes otherwise.

h Measured as a dummy variable where 1 denotes off-farm work (farmer and/or spouse) and 0 denotes no offfarm work.

${ }^{i}$ Measured as a dummy variable where 1 denotes off-farm investments the last five years and 0 denotes otherwise.

i Measured as percent of the farm's total standard gross margin (SGM) from the dairy enterprise.

${ }^{\mathrm{k}}$ Measured as a dummy variable where 1 denotes farm income $\geq$ NOK 200000 and 0 denotes otherwise.

${ }^{1}$ Measured as a dummy variable where 1 denotes household income $\geq$ NOK 350000 and 0 denotes otherwise.

$\mathrm{m}$ Measured as a dummy variable where 1 denotes central location (no regional policy priority) and 0 denotes otherwise, cf. KRD (2003).

${ }^{n}$ The Nagelkerke approach was used to determine the coefficient of determination (Pseudo- $\mathrm{R}^{2}$ ) in the ordered logit model.

egy, keeping fixed costs low (e.g. through hiring land and machinery), and a cross loading of product and market flexibility load significantly.

\subsection{Risk aversion and sources of risk in relation to farm and farmer characteristics}

A multi-response ordered logit model was used to examine the relationship between comparative risk aversion and socio-economic variables. For the sources of risk ordinary least square (OLS) multiple regressions were used. Regression coefficients and goodness-of-fit measures are presented in Table 5.

All models summarised in Table 5, except that for "human resources", were significant. Usually, goodness-of-fit is fairly low for discrete choice models 
(Verbeek, 2000, pp. 186). The specified logit model performed 12\% better than a model that specified the probability of take up to be constant.

The goodness-of-fit coefficients in the significant OLS models were low, except "organic farming", suggesting very personal perceptions and/or that important variables explaining farmers' perceptions have been excluded. Exclusion of many socio-economic variables of potential importance was judged not to be very likely.

The extremely low debt/asset ratios and high liquidity measures often found in farming are, however, consistent with risk aversion (Musser and Patrick, 2002), as shown for a solvency measure in Meuwissen et al. (2001). These issues could not be examined in our study. Farmer-specificity of perceptions is in line with previous studies (Boggess et al., 1985; Wilson et al., 1993; Patrick and Musser, 1997; Meuwissen et al., 2001).

Organic farmers had very significantly less comparative risk aversions (CRA) than conventional farmers, which is in agreement with the results presented in Fig. 2. Farmers having more dairy cows had a lower degree of CRA. Increased farm income implied, unexpectedly, higher degree of CRA. The last relationship may be of less economic importance, since it is the risk that threaten a farmer's long-term asset base that really matter (Just, 2003).

"Organic farming" was the only risk source organic farmers, compared to conventional farmers, perceived as significantly more important (column three to eight). In relation to organic farmers, conventional farmers perceived production, institutional and credit sources of risk as significantly more important, maybe related to their higher use of variable inputs.

Consumer demand was the only risk source factor that was significantly influenced by farmers' CRA. Both the most and least risk averse farmers found consumer demand risks more important than the medium risk averse farmers.

Of the other socio-economic characteristics, only off-farm investments and location had significant effects on the perceptions of risk sources. Farmers who had invested off-farm perceived credit risks as much less relevant, perhaps because their credit obligations are small. Farmers in central areas were more concerned about production risks, especially associated with the animal disease variables. The finding may be related to more frequent experiences with disease outbreaks in central areas (Norström et al., 2000; Nyberg et al., 2004) and therefore greater fear of these risk sources. Also, a higher frequency of livestock trade (Østerås, personal communication) and more densely populated areas may contribute to the greater disease concerns.

\subsection{Perceptions of risk management in relation to farm and farmer characteristics}

The last step was to use multiple linear regressions to relate the information on socio-economic characteristics and risk perceptions to management responses. The regression coefficients and the goodness-of-fit measures of the 
Table 6: $\quad$ Results of multiple regressions for risk management strategies ${ }^{\mathrm{a}}, \mathrm{n}=457$

\begin{tabular}{|c|c|c|c|c|c|c|c|}
\hline \multirow[t]{2}{*}{ Independent variables } & \multicolumn{7}{|c|}{ Risk management strategies } \\
\hline & (1) & $(2)$ & (3) & (4) & $(5)$ & $(6)$ & (7) \\
\hline Farming system ${ }^{b}$ & $(*)-0.22$ & $(*) 0.22$ & $(*) 0.24$ & -0.07 & -0.17 & -0.09 & -0.06 \\
\hline CRA: $m a-m^{c}$ & $*_{-} 0.18$ & $* 0.19$ & -0.07 & 0.13 & -0.05 & 0.13 & 0.04 \\
\hline CRA: la-me & 0.04 & $* 0.26$ & 0.16 & (*) 0.20 & 0.10 & -0.02 & $* 0.22$ \\
\hline Ownership $^{d}$ & -0.15 & -0.09 & -0.05 & -0.12 & 0.05 & -0.21 & $* * 0.45$ \\
\hline Number of cows & 0.00 & 0.01 & 0.00 & $* 0.01$ & 0.00 & 0.00 & 0.01 \\
\hline Farm experience (year) & -0.01 & 0.00 & -0.01 & $*_{-} 0.01$ & $* *_{-} 0.01$ & $* 0.01$ & 0.00 \\
\hline Education $^{\mathrm{e}}$ & 0.03 & -0.12 & 0.02 & -0.15 & (*) 0.17 & 0.15 & 0.11 \\
\hline Agricultural education ${ }^{\mathrm{f}}$ & 0.02 & -0.08 & 0.10 & 0.06 & 0.07 & 0.09 & $* * 0.21$ \\
\hline Off-farm workg & 0.06 & 0.03 & $* *_{-} 0.27$ & $* * 0.26$ & ${ }^{(*)} 0.14$ & -0.09 & 0.02 \\
\hline Off-farm investment ${ }^{\mathrm{h}}$ & 0.11 & -0.08 & -0.02 & -0.08 & $* * * 0.40$ & -0.04 & (*)_-0.14 \\
\hline SGM dairy $(\%)^{\mathrm{i}}$ & 0.01 & $*_{-} 0.65$ & $*_{-} 0.64$ & -0.25 & 0.05 & 0.30 & $(*) \_0.45$ \\
\hline Farm incomei & 0.04 & 0.02 & -0.06 & 0.09 & -0.03 & 0.06 & -0.03 \\
\hline Household income $\mathrm{k}^{\mathrm{k}}$ & -0.03 & -0.02 & 0.04 & 0.10 & -0.01 & -0.01 & -0.03 \\
\hline Geographyl & -0.07 & 0.07 & $* * 0.26$ & $*_{-} 0.18$ & -0.06 & -0.13 & -0.07 \\
\hline 1. Production ${ }^{\mathrm{m}}$ & $* * * 0.15$ & $* * * 0.18$ & $* * * 0.19$ & (*) 0.08 & 0.06 & $* * 0.14$ & 0.01 \\
\hline 2. Institutional & 0.03 & *0.10 & $(*) 0.09$ & 0.01 & 0.04 & $* * * 0.18$ & 0.02 \\
\hline 3. Organic farming & -0.03 & -0.06 & 0.02 & -0.07 & (*) 0.09 & $(*)_{-} 0.10$ & $* 0.11$ \\
\hline 4. Credit & $* * * 0.17$ & (*) 0.09 & 0.07 & 0.05 & 0.03 & -0.07 & $* 0.11$ \\
\hline 5. Consumer demand & 0.08 & $* 0.10$ & 0.06 & 0.05 & 0.01 & -0.03 & 0.02 \\
\hline 6. Human resources & 0.03 & 0.04 & 0.00 & (*) 0.09 & 0.03 & $* 0.11$ & -0.04 \\
\hline $\mathrm{R}_{\text {adj }}$ & $* * * 0.088$ & $* * * 0.082$ & $* * * 0.128$ & $* * * 0.085$ & $* * * 0.102$ & $* * * 0.119$ & $* * * 0.088$ \\
\hline
\end{tabular}

The strategies considered are (1) Consultancy; (2) Diseases; (3) Flexibility; (4) Insurance; (5) Diversification; (6) Financial; (7) Fixed cost.

a Variables and models significant at $\left.{ }^{*}\right) \mathrm{P}<0.10, * \mathrm{P}<0.05$, ${ }^{*} * \mathrm{P}<0.01$ and $* * * \mathrm{P}<0.001$.

b Measured as a dummy variable; 1 denotes organic farming and 0 denotes conventional farming.

c Measured as two dummy variables "ma-m" and "la-m"; 0 denotes the medium risk averse attitude (m), and 1 denotes the most risk averse attitude (ma) and the least risk averse attitude (la), respectively.

d Measured as a dummy variable where 1 denotes partnerships and 0 denotes otherwise.

e Measured as a dummy variable where 1 denotes formal schooling beyond high school and 0 denotes high school education or less.

${ }^{\mathrm{f}}$ Measured as a dummy variable where 1 denotes agricultural education and 0 denotes otherwise.

$\mathrm{g}$ Measured as a dummy variable where 1 denotes off-farm work (farmer and/or spouse) and 0 denotes no offfarm work.

h Measured as a dummy variable; 1 denotes off-farm investments in the last five years and 0 denotes otherwise.

${ }^{i}$ Measured as percent of the farm's total standard gross margin (SGM) from the dairy enterprise.

i Measured as a dummy variable where 1 denotes farm income $\geq$ NOK 200000 and 0 denotes otherwise.

k Measured as a dummy variable where 1 denotes household income $\geq$ NOK 350000 and 0 denotes otherwise

${ }^{1}$ Measured as a dummy variable where 1 denotes central location (no regional policy priority) and 0 denotes otherwise, cf. KRD (2003).

m Variables numbered "1-6" refer to sources of risk (from the factor analysis).

models are presented in Table 6. All models were highly significant and all of them explained around $10 \%$ of the total variance.

Organic farmers tended to perceive flexibility and disease prevention as more important and consultancy as less important than the conventional farmers. Compared to other farmers, the most risk averse farmers perceived disease management strategies as significantly more important and found consultancy less important. The least risk averse farmers were more likely to view disease prevention and fixed cost sharing as important management responses. 
All socio-economic variables, except education and the two income variables, had at least one significant relationship with the risk management strategies. In contrast, earlier studies have found some relationships between economic variables (like gross farm income and solvency) and farmers' perceptions of risk sources and management responses (Patrick and Musser, 1997; Meuwissen et al., 2001).

Farmers in partnerships perceived fixed cost sharing as more relevant than the others (mostly family farms). Farmers with larger herds were more likely to perceive insurance as relevant. More experienced farmers were significantly less concerned about insurance and diversification but found financial management responses more important. Farmers with education in agriculture placed more emphasis on fixed cost sharing. Off-farm work was associated with more importance assigned to insurance responses and less importance given to (on-farm) flexibility responses. Not surprisingly, investing off-farm was highly associated with diversification strategies. The most specialised dairy farmers perceived flexibility and disease prevention as less relevant. Farmers in central areas found flexibility more important, while insurance was of less concern.

The final independent variables are the perceived risk sources. An essential question is: How do farmers cope with the institutional risks? The regressions suggested that institutional risks are highly related to financial management responses (solvency, liquidity, low cost production). Disease prevention was also of importance. The results indicate multidimensionality of institutional risks requiring multiple management responses. More creative ways to handle risk than the traditional ones referred to in the survey may also be needed (Boehlje, 2003).

Production risks were found to be highly associated with multiple management responses; consultancy, disease prevention, flexibility and financial strategies. No one-to-one correspondence between sources of and responses to risk has also been observed previously (Patrick and Musser, 1997). Organic farming risks were positively related to fixed cost sharing. Consultancy and fixed cost sharing were important responses to credit risks. The risk source consumer demand was positively associated with disease prevention, maybe related to increased consumer awareness of animal health problems that can be reduced through a healthier herd. Farmers who perceived human resource risks to be important appreciated financial risk management strategies.

\section{Conclusions}

Our results suggest that organic farmers perceived themselves to be less risk averse than their conventional colleagues. Both groups perceived institutional risks as primary sources of risk, with farm support payments top rated. Conventional farmers perceived many sources of risk as more important than or- 
ganic farmers, the difference being most pronounced for costs of purchased inputs and animal welfare policy. Organic farmers gave more weight to institutional factors related to their production systems (organic farming payments, price premiums, and organic regulations).

Financial measures, disease prevention, and insurance were perceived as the most important risk management strategies. Organic and conventional farmers' management responses were relative similar but organic farmers rated flexibility as more important. Both institutional and production risks were associated with multiple ways to handle risk.

A number of socio-economic variables had significant effects on risk perceptions and management responses. More significant variables were found for management responses than for risk perceptions. The low explanatory power in the regression models may imply a high degree of farm-specific risk perceptions.

The high support payments and high degree of regulation of agriculture in Norway obviously impact upon our results. Nevertheless, the agricultural policy system is not very different from what is found in several other Northern countries. This implies that similar results could be found in other countries, as indicated in Finland (Sonkilla, 2002).

The study revealed notable differences between organic and conventional dairy farmers' risk perceptions, suggesting that government policies may have to be applied differently to the two groups. Both groups of farmers were, however, worried about the institutional risks, indicating the importance of an agricultural policy that is clear, stable and predictable. Policy makers should therefore be cautious about changing policy capriciously and they should consider the scope for strategic policy initiatives that give farmers some greater confidence about the longer term. One step in a more stable and predictable direction in Norway would be a change from annual to perennial agricultural negotiations between the farmers' unions and the government.

Risk research in agricultural economics and farm management has emphasised production and marketing risks (Musser and Patrick, 2002). Our findings suggest that more attention should be paid on studying institutional risks. Further, farm management consultants and advisers should make more use of decision analysis tools that incorporate institutional risks.

\section{References}

ALLAIS M. (1984) 'The foundations of the theory of utility and risk.' In: Hargen, O., Wenstrop, F. (Eds), Progress in Utility and Risk Theory. Reidel, Dordrecht, pp. 3-131.

BeLsLey D.A., KuH E., WelSCH R.E. (1980) Regression Diagnostics: Identifying influential Data and Sources of Collinearity. John Wiley \& Sons, New York. 
BOEHLJE M. (2003) 'Strategy development in a turbulent business climate: concepts and methods.' Staff Paper \# 03-06. Department of Agricultural Economics, Purdue University, West Lafayette.

Boggess W.G., ANAMAN K.A., HANSON G.D. (1985) 'Importance, causes, and management responses to farm risks: evidence from Florida and Alabama.' So. J. Agric. Econ. 17, 105-116.

EKERN A. (1991) 'Nytt system for energivurdering av fôr til drøvtyggere.' Nor. Landbruksforsk. 5, 273-277.

GARDEBROEK K. (2002) 'Are organic farmers less risk averse than non-organic farmers?' Paper presented at the Xth Congress of the European Association of Agricultural Economists (EAAE), Zaragoza, 28-31 August 2002.

HAIR J.F. JR., ANDERSON R.E., TATHAM R.L., BLACK W.C. (1998) Multivariate Data Analysis, 5th ed. Prentice Hall, Upper Saddle River.

Hall D.C., Knight T.O., Coble K.H., Baquet A.E., Patrick G.F. (2003) 'Analysis of beef producers' risk management perceptions and desire for further risk management education.' Rev. Agric. Econ. 25, 430-448.

Hardaker J.B., Huirne R.B.M, Anderson J.R., Lien G. (2004) Coping With Risk in Agriculture, 2nd ed. CABI Publishing, Wallingford.

Harwood J., Heifner R., Coble K., Perry J., Somwaru A. (1999) 'Managing risk in farming: concepts, research, and analysis.' Agricultural Economics Report No. 774. U.S. Department of Agriculture, Washington.

JUST R.E. (2003) 'Risk research in agricultural economics: opportunities and challenges for the next twenty-five years.' Agric. Syst. 75, 123-159.

KAHNEMAN D., TVERSKY A. (1979) 'Prospect theory: an analysis of decision under risk.' Econometrica 47, 263-291.

Koesling M., EbbesviK M., Lien G., Flaten O., VAlle P.S., ARntzen H. (2004) 'Risk and risk management in organic and conventional cash crop farming in Norway.' Acta Agric. Scand. Sect. C Food Econ. 1, 195206.

LD (Ministry of Agriculture) (2002) St.meld. nr. 12 (2002-2003) 'om dyrehold og dyrevelferd.' Det kongelige landbruksdepartement, Oslo.

KRD (Ministry of Local Government and Regional Development) (2003) 'Forskrift om investeringstilskot og avgrensing av det geografiske verkeområdet for dei regional- og distriktspolitiske verkemidla.' Kommunal- og regionaldepartementet, Oslo. 
MARCH J.G., SHAPIRA Z. (1987) 'Managerial perspectives on risk and risk taking.' Manage. Sci. 33, 1404-1418.

MARTIN S. (1996) 'Risk management strategies in New Zealand agriculture and horticulture.' Rev. Market. Agric. Econ. 64, 31-44.

MEuWissen M.P.M., Huirne R.B.M., HARDAKER J.B. (2001) 'Risk and risk management: an empirical analysis of Dutch livestock farmers.' Livest. Prod. Sci. 69, 43-53.

MEYER J. (2002) 'Expected utility as a paradigm for decision making in agriculture.' In: Just, R.E., Pope, R.D. (Eds), A Comprehensive Assessment of the Role of Risk in U.S. Agriculture. Kluwer, Boston, pp. 3-19.

Moschini G., HENNESSY D.A. (2001) 'Uncertainty, risk aversion, and risk management for agricultural producers.' In: Gardner, B., Rausser, G. (Eds), Handbook in Agricultural Economics, Volume 1A. Elsevier, Amsterdam, pp. 87-153.

Musser W.N., PATRICK G.F. (2002) 'How much does risk really matter to farmers?' In: Just, R.E., Pope, R.D. (Eds), A Comprehensive Assessment of the Role of Risk in U.S. Agriculture. Kluwer, Boston, pp. 537-556.

Norström M., PFEIFFER D.U., JARP J. (2000) 'A space-time cluster investigation of an outbreak of acute respiratory disease in Norwegian cattle herds.' Prev. Vet. Med. 47, 107-119.

Nyberg O. Gudmundsson S., Åkerstedt J. (2004) 'The surveillance and control programme for bovine virus diarrhoea (BVD) in Norway.' In: Mørk T., Hellberg H. (Eds), Surveillance and Control Programmes for Terrestrial and Aquatic Animals in Norway. Annual Report 2003. National Veterinary Institute, Oslo, pp. 72-77.

Offermann F., Nieberg H. (2000) 'Economic Performance of Organic Farms in Europe.' Organic farming in Europe: Economics and Policy, Volume 5. University of Hohenheim, Stuttgart.

PATRICK G.F., Musser W.N. (1997) 'Sources of and responses to risk: factor analyses of large-scale US cornbelt farmers.' In: Huirne, R.B.M., Hardaker, J.B., Dijkhuizen, A.A. (Eds), Risk Management Strategies in Agriculture; State of the Art and Future Perspectives. Mansholt Studies, Vol. No. 7. Wageningen Agricultural University, Wageningen, pp. 45-53.

PRIEM R.L., LOVE L.G., SHAFFER M.A. (2002) 'Executives' perceptions of uncertainty sources: a numerical taxonomy and underlying dimensions.' J. Manage. 28, 725-746.

RABIN M., Thaler R.H. (2001) 'Anomalies: risk aversion.' J. Econ. Persp. 15, 219-232. 
SLOVIC P., FISCHHOFF B., LICHTENSTEIN S. (1982) 'Facts versus fears: understanding perceived risk.' In: Kahneman, D., Slovic, P., Tversky, A. (Eds), Judgement under Uncertainty: Heuristics and Biases. Cambridge University Press, Cambridge, pp. 463-492.

SONKKILA S. (2002) Farmers' Decision-making on Adjustment into the EU. Publications No. 34. Department of Economics and Management, University of Helsinki, Helsinki.

Thaler R.H. (2000) 'From Homo Economicus to Homo Sapiens.' J. Econ. Perspect. 14, 133-141.

VAn RaAij W.F. (1981) 'Economic psychology.' J. Econ. Psychol. 1, 1-24.

VerbeEK M. (2000) A Guide to Modern Econometrics. John Wiley \& Sons, Chicester.

WHITE H. (1980) 'A heteroskedasticity-consistent covariance matrix estimator and a direct test for heteroskedasticity.' Econometrica 48, 817-838.

Wilson P.N., DAhlgRAN R.G., CONKLIN N.C. (1993) "Perceptions as reality" on large-scale dairy farms.' Rev. Agric. Econ. 15, 89-101.

ØsterÅs O. (2003) 'Helsekortordninga 2002.' Nor. Vet. Tidsskr. 115, 431-442. 